\title{
INDUCTION OF ASTROCYTIC CYCLOOXYGENASE-2 IN EPILEPTIC PATIENTS WITH HIPPOCAMPAL SCLEROSIS
}

\author{
Paul Desjardins ${ }^{a}$, Anny Sauvageau, ${ }^{a}$, Alain Bouthillier ${ }^{b}$, Darren Navarro ${ }^{a}$, Alan S \\ Hazella, Christopher Rose ${ }^{a}$, Roger F Butterworth ${ }^{\mathrm{a}}$
}

a Neuroscience Research Unit, C.H.U.M., Hôpital Saint-Luc, 1058 St. Denis Street, Montreal, Que., Canada H2X 3J4 b Departments of Pathology and Neurosurgery, C.H.U.M., Hôpital Notre-Dame, Montreal, Que., Canada

\section{ABSTRACT}

Induction of cyclooxygenase-2 (COX-2) has been described in a wide range of neurological diseases including animal models of epilepsy. The present study was undertaken to assess COX-2 expression in hippocampal biopsies from patients with therapy-refractive temporal lobe epilepsy (TLE). For this purpose, hippocampal CA1 subfield was dissected from epileptic patients with $(n=5)$ or without $(n=2)$ hippocampal sclerosis (HS). COX-2 expression was investigated using immunohistochemistry and semi-quantitative RT-PCR. COX-2 immunoreactivity in TLE patient material in the absence of HS was restricted to a few neurons of the hippocampus. In the presence of HS, on the other hand, a significant induction of astrocytic COX-2 immunoreactivity associated with a concomitant increase in the steady-state level of COX-2 mRNA was observed in the CA1 subfield. These findings suggest that induction of astrocytic COX-2 is implicated in the pathogenesis of HS in TLE and is consistent with the previous findings of increased concentrations of prostaglandins in the cerebrospinal fluid of these patients.

\section{KEYWORDS}

Temporal lobe epilepsy; Cyclooxygenase-2; Prostaglandins; Astrocytes

\section{INTRODUCTION}

Glutamate is the primary excitatory neurotransmitter of mammalian brain and abnormalities in the glutamate system have been implicated in experimental and human epilepsy (Meldrum, 1994). Overstimulation of N-methyl-daspartate (NMDA) receptors is associated with neuronal cell death in the pyramidal cell layers (CA regions) and dentate gyrus of the hippocampus and has been suggested to play a role in temporal lobe epilepsy (TLE) (Marthern et al., 1999). Stimulation of NMDA receptors activates calcium-dependent enzymes such as phospholipase A2, leading to accumulation of arachidonic acid and to its subsequent conversion into leukotrienes by 5-lipoxygenase or into prostaglandins and thromboxanes by cyclooxygenases (Shimizu and Wolfe, 1990). Cyclooxygenases, or prostaglandin endoperoxide synthases, catalyze the first committed enzymatic step in the formation of prostaglandins from arachidonic acid and exist in two isoforms. Cyclooxygenase- 1 is a constitutive enzyme associated with homeostatic functions, while cyclooxygenase-2 (COX-2) is associated with inflammation. COX-2 was initially described as a neuronal immediate-early gene inducible by seizures or NMDA-dependent synaptic activity ( Yamagata et al., 1993 and Marcheselli and Bazan, 1996). However, basal levels of COX-2 expression have been observed in neurons in the hippocampus as well as in other brain regions (Kaufmann et al., 1996). COX-2 is upregulated in a variety of other cell types by cytokines and growth factors and down-regulated by glucocorticoid hormones (Smith et al., 1996). COX-2 is also expressed by normal and reactive astrocytes in the adult rat central nervous system (Hirst et al., 1999). 
COX-2 expression in the brain is dramatically increased in a wide range of neurological disorders including cerebral ischemia (Iadecola et al., 1999), Alzheimer disease (Pasinetti and Aisen, 1998), and amyotrophic lateral sclerosis (Drachman and Rothstein, 2000). It has also been suggested that COX-2 and prostaglandins may play a role in epilepsy. For example, COX-2 expression is induced in hippocampus after kindling (Tu et al., 2000), in the genetically susceptible El mice (Okada et al., 2001), and in kainate-induced seizures (Hirst et al., 1999, Chen et al., 1995 and Sandhya et al., 1998). Newly synthesized COX-2 protein is known to contribute to NMDA-mediated neuronal cell death in cultured neurons (Hewett et al., 2000) and transgenic mice overexpressing neuronal COX-2 are more suspceptible to kainic acid excitotoxicity (Kelley et al., 1999), suggesting that induction of COX-2 could be responsible for tissue damage occurring during seizures in TLE. A major consequence of COX-2 activation is the generation of highly reactive oxygen free radical species with potentially damaging effects on lipids, proteins and DNA (Sun and Chen, 1998).

The present study was undertaken to assess COX-2 expression in hippocampal biopsies from patients with therapyrefractive TLE. For this purpose, the hippocampal CA1 subfield was dissected from surgical biopsy samples from groups of epileptic patients with or without hippocampal sclerosis (HS). COX-2 expression was investigated using immunohistochemistry and semi-quantitative reverse transcription-polymerase chain reaction (RT-PCR).

\section{EXPERIMENTAL PROCEDURES}

\section{Patients}

Surgical hippocampal specimens were obtained from epileptic patients with medial TLE with $(n=5)$, or without $(n=2)$ HS (Table 1). All patients suffered from complex partial seizures and the epileptic focus was localized to the temporal lobe in all patients as revealed by physical examination, MRI, and long-term video monitoring. The hippocampus was removed surgically from these patients in order to achieve seizure control. Hippocampal samples were rapidly frozen for molecular studies or immersion fixed in phosphate-buffered saline (PBS) for histological evaluation and subsequent correlative analysis. Hematoxylin-eosin staining of sections from TLE patients with HS revealed an almost complete loss of neurons from the CA1 subfield and astrocytosis (Sauvageau et al., 2001). The CA1 region was microdissected from frozen samples and kept at $-80{ }^{\circ} \mathrm{C}$ until RNA extraction. Ethical permission for this study was granted by the Ethics Committee of University of Montreal (CHUM).

Table 1. Comparison of clinical variables in epileptic patients with or without hippocampal sclerosis for COX-2 mRNA expression

\begin{tabular}{|c|c|c|c|c|c|c|}
\hline $\begin{array}{l}\text { Patient } \\
\text { number }\end{array}$ & Status & Sex & Age & $\begin{array}{l}\text { Number of seizures } \\
\text { (months) }\end{array}$ & $\begin{array}{l}\text { Age at seizure onset } \\
\text { (years) }\end{array}$ & $\begin{array}{l}\text { Duration of seizures } \\
\text { (years) }\end{array}$ \\
\hline 1 & $\begin{array}{l}\text { Non- } \\
\text { sclerotic }\end{array}$ & M & 15 & 25 & 9 & 6 \\
\hline 2 & $\begin{array}{l}\text { Non- } \\
\text { sclerotic }\end{array}$ & M & 32 & 6 & 13 & 19 \\
\hline 3 & Sclerotic & $\mathrm{F}$ & 30 & 10 & 20 & 10 \\
\hline 4 & Sclerotic & $\mathrm{M}$ & 44 & 15 & 18 & 26 \\
\hline 5 & Sclerotic & M & 34 & 52 & 5 & 32 \\
\hline 6 & Sclerotic & $\mathrm{F}$ & 29 & 4 & 5 & 24 \\
\hline 7 & Sclerotic & M & 30 & 11 & 6 & 24 \\
\hline
\end{tabular}

\section{IMMUNOHISTOCHEMISTRY}

Frozen sections $(6 \mu \mathrm{m})$ were fixed in methanol for $2 \mathrm{~min}$ at $-20^{\circ} \mathrm{C}$. The cell membranes were then permeabilized in PBS containing 1\% Triton X-100 for 30 min at room temperature. The sections were rinsed with PBS and incubated 
with $0.3 \% \mathrm{H}_{2} \mathrm{O}_{2}$ for 5 min to inactivate endogenous peroxidase. Non-specific sites were blocked in PBS containing $0.1 \%$ Triton X-100 (PBST) and 1.5\% heat-inactivated goat serum for $30 \mathrm{~min}$. Sections were incubated overnight at $4{ }^{\circ} \mathrm{C}$ with rabbit polyclonal antibody $(1 \mu \mathrm{g} / \mathrm{ml})$ directed against human COX-2 (Santa Cruz Biotechnology, CA). After washing with PBST, sections were incubated with biotinylated goat antibody against rabbit IgGs (Vector laboratory, CA) at a 1:200 dilution for $30 \mathrm{~min}$ at room temperature. Sections were washed with PBST and incubated with an avidin-biotin-peroxidase complex (Vectastain, Vector laboratory, CA) at a 1:500 dilution for $30 \mathrm{~min}$. After washing with PBST, bound immunoglobulins were detected by incubation with $0.1 \mathrm{M}$ Tris- $\mathrm{HCl}$ (pH 7.4) containing $0.5 \mathrm{mg} / \mathrm{ml}$ 3,3'-diaminobenzidine $(\mathrm{HCl})$ and $0.01 \%$ hydrogen peroxide. The sections were mounted on glass slides and counterstained with hematoxylin. Control sections were incubated with PBST instead of primary antibody; these showed absence of immunostaining.

\section{RNA extraction}

Total RNA was extracted using TRI Reagent (MRC Inc., Ohio) according to the manufacturer's protocol. Putative contaminating DNA was eliminated by adding $100 \mathrm{U}$ of RNase-free DNase I per $50 \mu \mathrm{g}$ of total RNA at $37^{\circ} \mathrm{C}$ for $1 \mathrm{~h}$. Purified RNA was then extracted with phenol, precipitated with ethanol and resuspended in diethylpyrocarbonatetreated water. RNA samples were kept at $-70^{\circ} \mathrm{C}$ until use.

\section{RT-PCR analysis}

$\beta$-Actin was used as an internal standard to monitor loading variations. Total RNA ( $0.5 \mu \mathrm{g})$ was mixed with $10 \mathrm{mM}$ Tris- $\mathrm{HCl}$ (pH 8.3), $1.0 \mathrm{mM} \mathrm{MgCl}_{2}, 50 \mathrm{mM} \mathrm{KCl}, 0.01 \%$ (w/v) bovine serum albumin, $100 \mu \mathrm{M}$ dNTPs, primers at $1 \mu \mathrm{M}$ each, AMV reverse transcriptase $(80 \mathrm{U} / \mathrm{ml})$, Taq DNA polymerase $(20 \mathrm{U} / \mathrm{ml})$ and $50 \mu \mathrm{Ci} / \mathrm{ml}[\alpha 32] \mathrm{dCTP}$ $(3000 \mathrm{Ci} / \mathrm{mmol})$, for a total reaction volume of $50 \mu \mathrm{l}$. Amplification efficiency conditions were determined after a kinetic study to ensure that the amount of the amplified product was linear with respect to the number of cycles (data not shown). The reactions were initially heated at $50^{\circ} \mathrm{C}$ for $15 \mathrm{~min}$ followed by PCR at $95^{\circ} \mathrm{C}$ for $30 \mathrm{~s}, 59^{\circ} \mathrm{C}$ for $45 \mathrm{~s}$ and $72{ }^{\circ} \mathrm{C}$ for $1 \mathrm{~min}$. $\beta$-Actin and COX- 2 were amplified for 20 and 27 cycles, respectively. After amplification, the samples were electrophoresed onto $9 \%$ polyacrylamide gels, dried, autoradiographed at $-70{ }^{\circ} \mathrm{C}$. Each band was excised and Cerenkov radiation was quantitated using a $\beta$-counter. Oligonucleotide primers were designed using the PRIME program (Genetic Computer Group, WI) and synthesized by the Sheldon Biotechnology Center (McGill University, Que.) based on the following GeneBank accession numbers: X00351 ( $\beta$-actin; Ponte et al., 1984), and L15326 (COX-2; Jones et al., 1993).The forward and reverse primer sequences were as follows: GACCTGACTGACTACCTCAT and AGACAGCACTGTGTTGGCGT ( $\beta$-actin, $350 \mathrm{bp}$ ); and CATTCTTTGCCCAGCACTTCAC and ATCATCAGACCAGGCACCAGAC (COX-2, $304 \mathrm{bp}$ ). The specificity of the oligonucleotide primers was verified using the program BLASTN (National Center for Biotechnology Information, Bethesda, MD).

\section{Statistical analysis}

Statistical significance of differences between the groups was determined by unpaired $t$-test.

\section{RESULTS}

COX-2 immunoreactivity in the CA1 hippocampal subfield of epileptic patients without HS was restricted to a few neurons (Fig. 1A). In contrast, a marked induction of COX-2 immunoreactivity was observed in the CA1 hippocampal subfield of all epileptic patients with HS. COX-2 immunolabelling in these latter cases was localized to astroglial cells, mainly astrocytes identified by the long and delicate stellate cytoplasmic processes (Fig. 1B, left panel) and the presence of numerous capillary end feet (Fig. 1B, right panel). Semi-quantitative RT-PCR analysis revealed a significant $43 \%$ increase $(\mathrm{P}<0.05)$ in the steady-state level of COX-2 mRNA (after normalization to $\beta$-actin) in the CA1 subfield of three epileptic patients with HS compared to patients without HS (Fig. 2). The variation observed in the steady-state levels of COX-2 mRNA in epileptic patients with HS may reflect the very short half-life of COX-2 mRNA (not more than $3.5 \mathrm{~h}$ ) in human brain (Lukiw and Bazan, 1997). Linear regression analysis of COX-2 mRNA 
levels did not reveal any significant correlation with the frequency ( $r=-0.60 ; P=0.28)$, the age of onset $(r=0.20$; $\mathrm{P}=0.74)$ or the duration of seizures $(\mathrm{r}=-0.73 ; \mathrm{P}=0.16)$ (Table 1$)$.
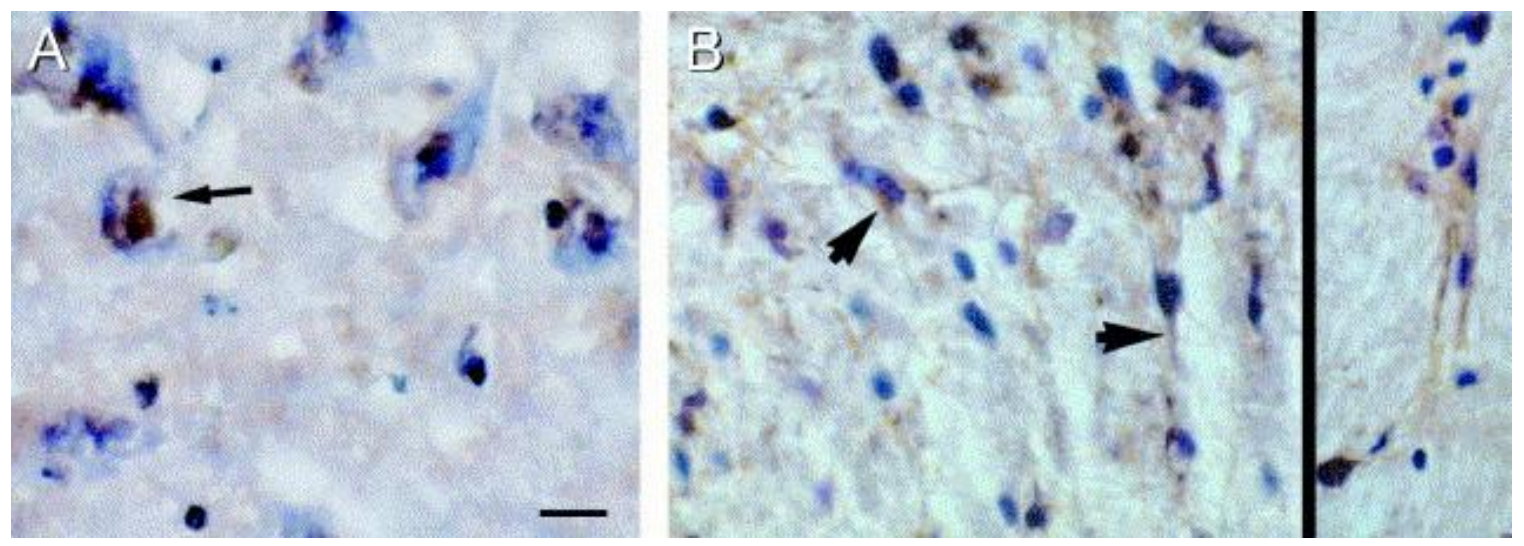

Fig. 1. Increased COX-2 immunoreactivity in the CA1 subfield of patients with TLE. (A) COX-2 immunoreactivity in non-HS patients; (B) COX-2 immunoreactivity in HS patients. Note the neuronal localization of COX-2

immunolabeling (arrow) in (A) and immunolabeling in cytoplasm and astrocytic processes (arrow heads) in (B) (left panel) as well as in juxtaposition to capillary end-feet (right panel). Scale bar for both figures (A) and (B) is $10 \mu \mathrm{m}$; $\times 600$.

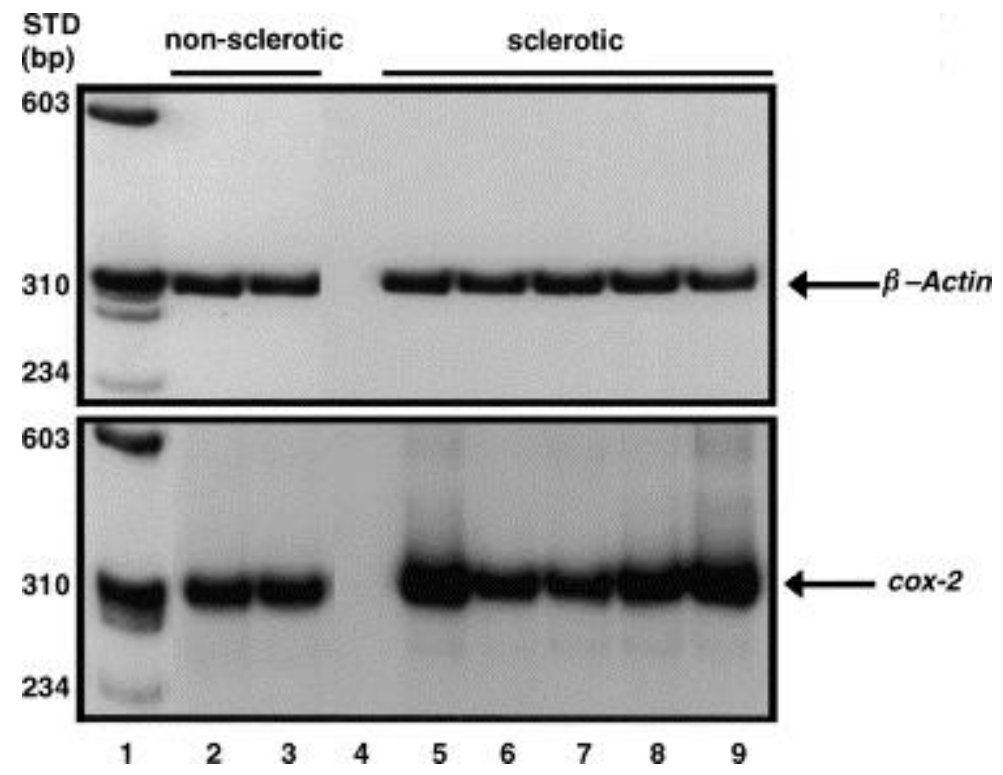

Fig. 2. Increased expression of $C O X-2$ mRNA in the CA1 subfield of epileptic patients. Total RNA was extracted from the CA1 regions of biopsies from five epileptic patients with hippocampal sclerosis (HS: lanes 5-9) and from two epileptic patients without hippocampal sclerosis (non-HS: lanes 2 and 3). $\beta$-Actin and COX-2 mRNAs were reversetranscribed and amplified by PCR as described in Experimental procedures. Lane 1: molecular weight standard; Lane 4: AMV reverse-transcriptase was omitted (as a negative control) from the reaction mixture. 


\section{DISCUSSION}

Results of the present study reveal a significant induction of astrocytic COX-2 mRNA and protein in the CA1 hippocampal subfield in surgical biopsies from patients with TLE. Although, on a limited number of cases, this study represents the first investigation of COX-2 expression in human TLE. These findings are consistent with the increased levels of prostaglandins found in the cerebrospinal fluid of epileptic patients (Wolfe and Mamer, 1975) and in the brains of animals with experimental epilepsy (Bazan et al., 1986).

Our findings also confirm and extend previous observations from animal models of TLE. For example, expression of COX-2 in rat brain is increased markedly in neurons a few hours following kainic acid administration and precedes neuronal cell death (Chen et al., 1995). COX-2 expression in reactive astrocytes, however, has been observed and found to persist for several weeks after kainate administration (Sandhya et al., 1998). Although, the exact contribution of COX-2 to the epileptogenesis process remains uncertain, the present findings of induction of astrocytic COX-2 in therapy-refractive TLE patients with longstanding and progressive HS may have profound effects on brain function. Activation of the astrocytic metabolism of arachidonic acid leading to increased prostagandin synthesis may promote neuronal damage, either directly through the production of oxygen radicals (Kontos and Povlishock, 1986), or indirectly by modulating glutamate neurotransmitter release and uptake (Gegelashvili and Schousboe, 1997, Manzoni and Mennini, 1997 and Bezzi et al., 1998). Accordingly, drugs that inhibit COX activity such as indomethacin, or selective COX-2 inhibitors such as rofecoxib have been found to reduce seizure frequencies and hippocampal cell death in several animal models of epilepsy (Wallenstein, 1987, Wallenstein, 1991, Baran et al., 1994, Paoletti et al., 1998, Kunz and Oliw, 2001 and Okada et al., 2001).

In view of the roles played by prostaglandins in brain inflammation and of the increased prostaglandin concentrations found in the cerebrospinal fluid of epileptic patients (Wolfe and Mamer, 1975), the present study suggests that induction of astrocytic COX-2 may play a role in the pathophysiology of epilepsy and/or in the pathogenesis of epileptic brain damage. These new findings also suggest that selective COX-2 inhibitors such as the non-steroidal anti-inflammatory drugs may provide novel anti-epileptic or neuroprotective strategies in human TLE.

\section{ACKNOWLEDGEMENTS}

This work was supported by a grant from the Savoy Foundation. P. Desjardins is the recipient of a fellowship from Claude Bertrand Foundation, University of Montreal.

\section{REFERENCES}

H Baran, K Vass, H Lassmann, 0 Hornykiewicz The cyclooxygenase and lipooxygenase inhibitor BW755C protects rats against kainic acid-induced seizures and neurotoxicity Brain Res., 646 (1994), pp. 201-206

N.G Bazan, D.L Birkle, W Tang, T.S Reddy The accumulation of free archidonic acid, diaglycerols, prostaglandins, and lipoxygenase reaction products in the brain during experimental epilepsy Adv. Neurol., 44 (1986), pp. 879-902

P Bezzi, G Carmignoto, L Pasti, S Vesce, D Rossi, B.L Rizzini, T Pozzan, A Volterra Prostaglandins stimulate calcium-dependent glutamate release in astrocytes Nature, 391 (1998), pp. 281-285

J Chen, T Marsh, J.S Zhang, S.H Graham Expression of cyclooxygenase-2 in rat brain following kainate treatment NeuroReport, 6 (1995), pp. 245-248

D.B Drachman, J.D Rothstein Inhibition of cyclooxygenase-2 protects motor neurons in an organotypic model of amyotrophic lateral sclerosis Ann. Neurol., 48 (2000), pp. 792-795

The final publication is available at http://dx.doi.org/10.1016/S0197-0186(02)00101-8 
Desjardins, P. et al., 2003. Induction of astrocytic cyclooxygenase-2 in epileptic patients with hippocampal sclerosis.

Neurochemistry International, 42(4), p.299-303.

G Gegelashvili, A Schousboe High affinity glutamate transporters: regulation of expression and activity Mol. Pharmacol., 52 (1997), pp. 6-15

S.J Hewett, T.F Uliasz, A.S Vidwans, J.A Hewett Cyclooxygenase-2 contributes to $N$-methyl-d-aspartate-mediated neuronal cell death in primary cortical cell cultureJ. Pharmacol. Exp. Ther., 293 (2000), pp. 417-425

W.D Hirst, K.A Young, R Newton, V.C Allport, D.R Marriott, G.P Wilkin Expression of COX-2 by normal and reactive astrocytes in the adult rat central nervous system Mol. Cell. Neurosci., 13 (1999), pp. 57-68

C Iadecola, C Forster, S Nogawa, H.B Clark, M.E Ross Cyclooxygenase-2 immunoreactivity in the human brain following cerebral ischemia Acta Neuropathol., 98 (1999), pp. 9-14

D.A Jones, D.P Carlton, T.M McIntyre, G.A Zimmerman, S.M Prescott Molecular cloning of human prostaglandin endoperoxide synthase type II and demonstration of expression in response to cytokines J. Biol. Chem., 268 (1993), pp. 9049-9054

W.E Kaufmann, P.F Worley, J Pegg, M Bremer, P Isakson COX-2, a synaptically induced enzyme, is expressed by excitatory neurons at postsynaptic sites in rat cerebral cortex Proc. Natl. Acad. Sci. U.S.A., 93 (1996), pp. 2317-2321

K.A Kelley, L Ho, D Winger, J Freire-Moar, C.B Borelli, P.S Aisen, G.M Pasinetti Potentiation of excitotoxicity in transgenic mice overexpressing neuronal cyclooxygenase-2 Am. J. Pathol., 155 (1999), pp. 995-1004

H.A Kontos, J.T Povlishock Oxygen radicals in brain injury Cent. Nerv. Syst. Trauma, 3 (1986), pp. 257-263

T Kunz, E.H Oliw The selective cyclooxygenase-2 inhibitor rofecoxib reduces kainate-induced cell death in the rat hippocampus Eur. J. Neurosci., 13 (2001), pp. 569-575

W.J Lukiw, N.G Bazan Cyclooxygenase-2 RNA message abundance, stability, and hypervariability in sporadic Alzheimer neocortex J. Neurosci. Res., 50 (1997), pp. 937-945

C Manzoni, T Mennini Arachidonic acid inhibits 3H-glutamate uptake with different potencies in rodent central nervous system regions expressing different transporter subtypes Pharmacol. Res., 35 (1997), pp. 149-151

V.L Marcheselli, N.G Bazan Sustained induction of prostaglandin endoperoxide synthase-2 by seizures in hippocampus J. Biol. Chem., 271 (1996), pp. 24794-24799

G.W Marthern, J.K Pretorius, D Mendoza, J.P Leite, L Chimelli, D.E Born, I Fried, J.A Assirati, G.A Ojemann, P.D Adelson, L.D Cahan, H.I Kornblum Hippocampal $N$-methyl-d-aspartate receptor subunit mRNA levels in temporal lobe epilepsy patients Ann. Neurol., 46 (1999), pp. 343-358

B.S Meldrum The role of glutamate in epilepsy and other CNS disorders Neurology, 44 (1994), pp. S14-S23

K Okada, T Yuhi, S Tsuji, U Yamashita Cyclooxygenase-2 expression in the hippocampus of genetically epilepsy susceptible El mice was increased after seizure Brain Res., 894 (2001), pp. 332-335

G.M Pasinetti, P.S Aisen Cyclooxygenase-2 expression is increased in frontal cortex of Alzheimer's disease brain Neuroscience, 87 (1998), pp. 319-324

A.M Paoletti, S Piccirilli, N Costa, D Rotiroti, G Bagetta, G Nisticò Systemic administration of $N$-omega-nitro-l-arginine methyl ester and indomethacin reduces the elevation of brain PGE2 content and prevents seizures and hippocampal damage evoked by LiCl and Tacrine in rat Exp. Neurol., 149 (1998), pp. 349-355

P Ponte, S.Y Ng, J Engel, P Gunning, L Kedes Evolutionary conservation in the untranslated regions of actin mRNAs: DNA sequence of a human beta-actin cDNA Nucl. Acids Res., 12 (1984), pp. 1687-1696

T.L Sandhya, W.Y Ong, L.A Horrocks, A.A Farooqui A light and electron microscopic study of cytoplasmic phopholipase A2 and cyclooxygenase-2 in the hippocampus after kainate lesions Brain Res., 788 (1998), pp. 223-231

The final publication is available at http://dx.doi.org/10.1016/S0197-0186(02)00101-8 
Desjardins, P. et al., 2003. Induction of astrocytic cyclooxygenase-2 in epileptic patients with hippocampal sclerosis. Neurochemistry International, 42(4), p.299-303.

A Sauvageau, P Desjardins, V Lozeva, C Rose, A.S Hazell, A Bouthillier, R.F Butterworth Increased expression of peripheral-type benzodiazepine receptors in human temporal lobe epilepsy: implications for PET imaging of hippocampal sclerosis Metab. Brain Dis., 17 (2001), pp. 233-241

T Shimizu, L.S Wolfe Arachidonic acid cascade and signal transduction J. Neurochem., 55 (1990), pp. 1-15

W.L Smith, R.M Garavito, D.L DeWitt Prostaglandin endoperoxide H synthases (cyclooxygenase)-1 and -2 J. Biol. Chem., 271 (1996), pp. 33517-33560

Y.L Sun, Y.M Chen Oxidative stress and neurodegenerative disorders J. Biomed. Sci., 5 (1998), pp. 401-414

B Tu, V.L Marcheselli, N.G Bazan COX-2 protein expression is induced in hippocampus and is potentiated in cortex by hippocampal kindling Soc Neuroscience, 26 (2000), p. 1000 (abstract)

K Yamagata, K.I Andreasson, W.E Kaufmann, C.A Barnes Expression of a mitogen-inducible cyclooxygenase in brain neurons: regulation by synaptic activity and glucocorticoids Neuron, 11 (1993), pp. 371-386

M.C Wallenstein Attenuation of penicillin models of epilepsy by nonsteroidal anti-inflammatory drugs Exp. Neurol., 98 (1987), pp. 152-160

M.C Wallenstein Attenuation of epileptogenesis by nonsteroidal anti-inflammatory drugs in the rat Neuropharmacology, 30 (1991), pp. 657-663

L.S Wolfe, O.A Mamer Measurement of prostaglandin F2 alpha levels in human cerebrospinal fluid in normal and pathological conditions Prostaglandins, 9 (1975), pp. 183-192 